\title{
HDC wt Allele
}

National Cancer Institute

\section{Source}

National Cancer Institute. HDC wt Allele. NCI Thesaurus. Code C90137.

Human HDC wild-type allele is located within 15q21-q22 and is approximately $24 \mathrm{~kb}$ in length. This allele, which encodes histidine decarboxylase protein, is involved in the regulation of histamine synthesis. A mutation in the gene may be associated with Tourette syndrome. 